\title{
PENGARUH METODE BERCERITA TERHADAP KEMAMPUAN MENGUNGKAPKAN BAHASA ANAK USIA 5-6 TAHUN DI TK PERTIWI 1 BANJARSARI
}

\author{
Gana Kartinika Hadi \\ Program Studi Pendidikan Guru Pendidikan Anak Usia Dini Fakultas Ilmu Pendidikan \\ Universitas Trunojoyo Madura \\ Email: ganakartinikahadi@gmail.com
}

Received August 2018, Accepted September 2018, Published October 2018

\begin{abstract}
The purpose of this study is to reveal the influence of storytelling method toward the ability of revealed language of the Child Aged 5-6 Years Old at Pertiwi 1 Banjarsari. This research uses quantitative approach by using experiment method; the research design uses Pre-Experimental design (nondesign) which includes pretest and pos-test. Subject of this research is a child aged 5-6 years old in Pertiwi 1 Banjarsari Kindergarten about 19 students. Data collecting technique through the observation and documentation. Data analysis technique the inferensial statistics by using $t$ data experiment analysis (T-Test). The result of data analysis is acquired value $r=0,68, t_{\text {table }}>t_{\text {count }}$ wich are $-2,450>-11,66$, thus $H_{a}$ is accepted wich means there is significanct influence between Sorytelling Method to child's revealed language ability.
\end{abstract}

Keywords: Storytelling Method, Ability of Revealed Language, Early Childhood Education

Abstrak: Tujuan penelitian ini yaitu untuk mengetahui pengaruh metode bercerita terhadap kemampuan mengungkapkan bahasa anak usia 5-6 tahun di TK Pertiwi 1 Banjarsari. Penelitian ini menggunakan pendekatan kuantitatif dengan metode eksperimen dengan desain penelitian Pre-Eksperimental Design (non designs) jenis one-group pretest-postest. Subjek dalam penelitian ini merupakan anak usia 5-6 tahun TK Pertiwi 1 Banjarsari sebanyak 19 anak. Teknik pengumpulan data melalui observasi dan dokumentasi. Teknik analisis data dalam penelitian ini menggunakan statistik inferensial parametris dengan menggunakan teknik analisis data uji t $(T$ Test). Hasil analisis data diperoleh nilai $\mathrm{r}=0,68, t_{\text {tabel }}>t_{\text {hitung }}$ yaitu $-2,450>-11,66$ maka $H_{a}$ diterima yang artinya ada pengaruh signifikan antara metode bercerita terhadap kemampuan mengungkapkan bahasa anak.

Kata Kunci: Metode Bercerita, Kemampuan menngungkapkan Bahasa, Pendidikan Anak Usia Dini.

\section{PENDAHULUAN}

Pendidikan merupakan dasar yang penting bagi kemajuan sebuah bangsa, karena dengan pendidikan sebuah bangsa akan mencapai kemajuan, baik dalam Sumber Daya Manusia (SDM) maupun Sumber Daya Alam (SDA). Pendidikan yang di mulai sejak usia dini merupakan suatu upaya untuk mempersiapkan SDM yang berkualitas. Pendidikan Anak Usia Dini (PAUD) sebagai pendidikan yang diselenggarakan untuk ditujukan pada kelompok anak usia lahir sampai dengan usia 6 tahun, pada usia ini sering disebut masa emas perkembangan. Pemberian pendidikan sejak dini yang baik pada anak akan memberi pengaruh pada proses perkembangan anak karena perkembangan merupakan tahapan dari perubahan aspek jasmani dan rohani manusia kearah yang lebih maju.

Pendidikan yang khusus mengarah kepada anak usia dini, yaitu telah diatur dalam Undang-Undang Nomor 20 Tahun 2003 tentang Sistem Pendidikan Nasional (Pasal 1 angka 14) menyatakan bahwa Pendidikan Anak Usia Dini (PAUD) adalah "Suatu upaya pembinaan yang ditujukan kepada anak sejak lahir sampai dengan usia enam tahun yang dilakukan melalui pemberian rangsangan pendidikan untuk membantu pertumbuhan dan perkembangan jasmani dan rohani agar anak memiliki kesiapan-kesiapan dalam memasuki pendidikan lebih lanjut baik pendidikan secara formal di sekolah maupun nonformal".

Pendidikan anak usia dini merupakan suatu bentuk penyelenggaraan pendidikan yang menitikberatkan pada peletakan dasar ke arah pertumbuhan dan perkembangan fisik (koordinasi motorik halus dan kasar), kecerdasan kognitif (daya pikir, daya cipta, kecerdasan emosi, kecerdasan spiritual), sosio emosional bahasa dan komunikasi, sesuai dengan keunikan dan tahap-tahap perkembangan sesuai kelompok usia yang dilalui oleh anak usia dini. Oleh karena itu, 
anak sebagai generasi yang unggul tidak akan tumbuh dengan sendirinya, akan tetapi anak memerlukan lingkungan yang baik dan tepat untuk dapat mengembangkan berbagai potensi maupun kecerdasan yang dimilikinya untuk bisa menjadi generasi yang unggul.

Mencetak generasi yang unggul dapat dilakukan melalui pendidikan yang memberikan kesempatan kepada anak untuk tumbuh dan berkembang sesuai dengan potensi, bakat, dan minat anak. Anak usia dini tentu berbeda dengan orang dewasa. Anak usia dini adalah individu yang sedang menjalani suatu proses perkembangan yang pesat bagi perkembangan selanjutnya. Terdapat potensi dan aspek-aspek perkembangan anak yang sebisa mungkin harus dirangsang melalui program pendidikan.

Pendidikan anak usia dini di Indonesia memiliki dampak yang cukup luas untuk mendorong pemahaman dan kesadaran masyarakat akan pentingnya pendidikan bagi anak usia dini. Hal ini terbukti dengan semakin banyaknya lembaga-lembaga pendidikan anak usia dini di Indonesia seperti, Tempat Penitipan Anak (TPA) untuk anak usia 0-2 tahun, Kelompok Bermain (Play Group) untuk anak usia 3-4 tahun, Taman Kanak-Kanak (TK) dan Raudatul Athfal (RA) untuk anak usia 4-6 tahun. Lembaga-lembaga pendidikan anak usia dini tersebut terdapat di berbagai wilayah di Indonesia, mulai dari perkotaan hingga di pedesaan yang dinaungi oleh pemerintah maupun yayasan. Di desa Banjarsari sendiri juga terdapat lembaga PAUD berjumlah 5, 1 Kelompok Bermain (Play Group), 2 Taman Kanak-Kanak (TK), dan 2 Raudatul Athfal (RA). Dimana dalam pendidikan tersebut terjadi sebuah proses pembelajaran yang dilaksanakan oleh guru dan anak.

Pelaksanaan proses pembelajaran di kelas merupakan salah satu upaya yang dilakukan oleh pendidik untuk mengembangkan potensi yang dimiliki anak. Seorang pendidik harus melibatkan anak dalam proses pembelajaran. Hubungan antara guru dengan anak harus terjalin secara berkesinambungan agar tercapai proses pembelajaran yang lebih optimal. Proses pembelajaran pada anak usia dini dilakukan dengan menggunakan berbagai jenis metode yang mampu mengembangkan aspek-aspek perkembangan pada diri anak. Metode pembelajaran anak usia dini diterapkan guru dalam proses pembelajaran agar tujuan pembelajaran yang telah ditetapkan bersama dapat tercapai dan berjalan secara maksimal.

Terdapat bermacam-macam metode pembelajaran pada anak usia dini yang dapat digunakan oleh guru, antara lain yaitu metode ceramah, metode tanya jawab, metode pembiasaan, metode keteladanan, metode bermain, demonstrasi, dan metode bercerita. Metode bercerita sangat umum digunakan dalam pembelajaran anak usia dini. Karena anak sangat menyukai cerita- cerita sehingga dapat membantu memotivasi anak untuk belajar.

Bercerita merupakan salah satu metode yang digunakan untuk pengembangan bahasa dan merupakan kegiatan berbahasa yang bersifat produktif karena melibatkan pikiran, kesiapan mental, keberanian, perkataan yang jelas sehingga dapat dipahami oleh orang lain. Metode bercerita merupakan cara penyampaian sebuah materi pembelajaran secara lisan dalam bentuk cerita. Metode bercerita sering digunakan oleh guru untuk mengembangkan berbagai aspek pada diri anak dan dapat memberikan pesan edukatif serta menghasilkan bahasa yang benar dan bermakna pada anak.

Cerita dapat merangsang imajinasi anak, selain itu cerita dapat membuat anak tidak hanya menyimak dan mendengarkan cerita tetapi juga membuat anak untuk senang bercerita. Melalui bercerita anak belajar tata cara berdialog dan bernarasi. Selain itu menurut Armstrong, salah satu upaya yang dapat digunakan untuk membantu mengembangkan kemampuan berbahasa anak yaitu dengan metode bercerita atau mendongeng, karena bercerita bukan hanya kegiatan yang bersifat hiburan bagi anak-anak melainkan sebuah kegiatan yang memiliki manfaat besar dalam mengembangkan berbagai pengetahuan anak. Penggunaan metode bercerita pada pendidikan anak usia dini sangat bermanfaat bagi perkembangannya.

Penggunaan metode bercerita dalam proses pembelajaran pada pendidikan anak usia dini adalah untuk memperkenalkan, memberi keterangan, atau penjelasan tentang hal baru dalam rangka menyampaikan pembelajaran yang dapat mengembangkan berbagai aspek perkembangan pada anak. Perkembangan anak usia dini harus distimulus sejak usia prasekolah 
agar berkembang sesuai dengan tingkat usia perkembangannya. Aspek perkembangan anak usia dini diantaranya yaitu moral agama, kognitif, fisik motorik, sosial emosional, seni kreativitas, dan bahasa. Salah satu kemampuan yang sangat penting dan harus dikembangkan yaitu kemampuan bahasa. Karena bahasa merupakan alat untuk berkomunikasi dan mengungkapkan pikiran serta perasaan kepada orang lain.

Anak usia dini berada dalam fase perkembangan bahasa secara ekspresif. Bahasa ekspresif merupakan kemampuan yang dimiliki anak untuk mengungkapkan apa yang menjadi keinginannya. Anak telah dapat mengungkapkan keinginannya, penolakannya, maupun pendapatnya dengan menggunakan bahasa lisan. Selain itu aspek perkembangan bahasa pada anak usia dini berdasarkan pada Peraturan Menteri Pendidikan Nasional Nomor 58 Tahun 2009 meliputi tiga aspek yaitu memahami bahasa, mengungkapkan bahasa dan keaksaraan.

Aspek kemampuan mengungkapkan bahasa anak usia dini merupakan kemampuan yang dimiliki anak untuk mengungkapkan apa yang diinginkannya sesuai dengan pikiran dan perasaan anak. Dalam Peraturan Menteri Pendidikan dan Kebudayaan Nomor 137 Tahun 2014 Tentang Standar Pendidikan Anak Usia Dini dalam aspek kemampuan mengungkapkan bahasa anak usia 5-6 tahun terdapat indikator pencapaian sesuai dengan tahap perkembangannya, antara lain yaitu menjawab pertanyaan yang lebih kompleks, berkomunikasi secara lisan, memiliki perbendaharaan kata, serta mengenal simbolsimbol persiapan membaca dan menulis, menyusun kalimat sederhana dalam struktur lengkap, memiliki lebih banyak kata-kata untuk mengekspresikan ide pada orang lain, melanjutkan sebagian cerita/dongeng yang telah diperdengarkan, menunjukkan pemahaman isi cerita.

Kemampuan mengungkapkan bahasa sebagai salah satu dari kemampuan dasar yang harus dimiliki anak, terdiri dari beberapa tahapan sesuai dengan usia dan karakteristik perkembangannya. Kemampuan mengungkapkan bahasa penting dimiliki oleh setiap anak karena dapat digunakan untuk mengungkapkan pikiran dan pendapat pada orang lain. Selain itu, agar anak memiliki pemahaman dalam berkomunikasi dengan individu lain baik anak maupun orang dewasa. Kemampuan mengungkapkan bahasa anak harus dikembangkan sejak usia dini agar anak mampu berbahasa dan berkomunikasi dengan baik dan benar kepada semua orang. Oleh karena itu, kemampuan mengungkapkan bahasa sangat penting dalam perkembangan anak usia dini. Peran orang tua dan guru sangat diharapkan untuk mampu memberikan stimulus yang sesuai sehingga kemampuan mengungkapkan bahasa anak dapat berkembang secara optimal.

Berdasarkan hasil observasi lanjutan dan wawancara lanjutan yang di lakukan pada Agustus 2017 di TK Pertiwi 1 Banjarsari dikarenakan observasi terdahulu dilakukan pada anak kelompok B yang sudah keluar dan melanjutkan ke jenjang pendidikan selanjutnya sehingga dilakukan observasi dan wawancara lanjutan yang hasilnya diketahui bahwa, guru setiap harinya menerapkan metode bercerita pada anak kelompok B. Kegiatan bercerita ini diterapkan hanya sebagai kegiatan awal atau kegiatan pengantar yang berlangsung setiap pagi sebelum kegiatan inti dilakukan. Guru menerapkan metode bercerita dengan menggunakan buku cerita bergambar atau majalah yang disampaikan kepada anak dan juga tidak jarang guru meminta salah satu anak ke depan untuk menyampaikan cerita dengan bantuan guru dan anak yang lain menyimak dan mendengarkan. Ketika kegiatan bercerita berlangsung, dapat dikatakan bahwa kemampuan mengungkapkan bahasa anak masih belum berkembang.

Hal tersebut terlihat dari beberapa anak yang ada pada kelompok B yang semua jumlah siswanya terdiri dari 32 anak. 13 anak terlihat kemampuan mengungkapkan bahasa anak sudah berkembang, dapat diketahui anak sudah mampu mengenal simbol huruf dan angka untuk persiapan membaca dan menulis, sedangkan terdapat 19 anak yang kemampuan mengungkapkan bahasanya masih belum berkembang. Diantaranya yaitu anak masih belum mampu menyampaikan ide-idenya karena kurangnya perbendaharaan kata, anak masih belum mampu mengulang kalimat cerita yang disampaikan oleh guru, ketika anak diminta oleh guru maju ke depan kelas untuk menceritakan kembali dari cerita yang sudah didengarnya, mereka masih kebingungan dan 
masih belum mampu untuk merangkai kalimat dengan baik, anak masih menggunakan bahasa daerah serta belum mampu menggunakan bahasa indonesia dengan benar dan lancar. Indikator pencapaian di atas didasarkan dari Standar Tingkat Pencapaian Perkembangan Anak.

Berdasarkan latar belakang di atas yang menguraikan mengenai metode bercerita dan kemampuan mengungkapkan bahasa pada anak usia 5-6 tahun di TK Pertiwi 1 Banjarsari, maka peneliti tertarik untuk mengadakan sebuah penelitian yang berjudul "Pengaruh Metode Bercerita terhadap Kemampuan Mengungkapkan Bahasa Anak Usia 5-6 Tahun Di TK Pertiwi 1 Banjarsari”.

\section{METODE PENELITIAN}

Metode penelitian dalam penelitian ini adalah metode penelitian eksperimen. Sugiyono (2014:14) menjelaskan bahwa metode penelitian eksperimen dapat diartikan sebagai metode penelitian yang digunakan untuk mencari pengaruh perlakuan tertentu terhadap yang lain dalam kondisi yang terkendalikan. Jenis yang digunakan PreEksperimental Design dengan desain penelitian One Group Pretest-Posttest Design, dimana dalam penelitiannya terdapat pretest dan posttest yang dilakukan untuk mengetahui dan membandingkan kemampuan klasifikasi warna sebelum dan sesudah diberi perlakuan.

Populasi dalam penelitian ini merupakan semua siswa usia 5-6 tahun TK Pertiwi 1 Banjarsari Desa Banjarsari Kecamatan Ngronggot Kabupaten Nganjuk yang berjumlah 32 anak. Sedangkan sampel yang representatif atau mewakili dalam penelitian ini yaitu 19 anak dalam kelompok B usia 5-6 tahun di TK Pertiwi 1 Banjarsari Desa Banjarsari Kecamatan Ngronggot Kabupaten Nganjuk, yang mana dalam pengambilan sampel menggunakan teknik non probability, dengan jenis sampling purposive.

Teknik pengumpulan data yang digunakan dalam penelitian yaitu observasi dan dokumentasi. Peneliti menggunakan observasi terstruktur. Penelitian ini peneliti menggunakan pedoman observasi dengan daftar cek/checklist yang berupa skala pengukuran skala rating scale dengan menggunakan 4 opsi yaitu belum berkembang, mulai berkembang, berkembang sesuai harapan, dan berkembang sangat baik.
Teknik pengumpulan data selanjutnya yaitu dokumentasi. Teknik ini digunakan untuk mengumpulkan data berupa perangkat pembelajaran seperti hasil karya anak, RPPH, surat keterangan, dan foto-foto proses pembelajaran menggunakan metode bermain fun cooking yang dilakukan pada kelompok B di TK Pertiwi 1 Banjarsari berlangsung mulai dari pretest, treatment, dan posttest

Perhitungan analisis data dalam penelitian ini menggunakan analisis regresi dengan uji-t (t-test), tujuan uji $\mathrm{t}$ adalah untuk mengetahui ada tidaknya pengaruh atau perbedaan nilai rata-rata antara dua kelompok data yang berpasangan. Penggunaan uji-t dua variabel dapat digunakan dengan rumus sebagai berikut:

$$
t=\frac{\bar{x}_{1}-\bar{x}_{2}}{\sqrt{\frac{s_{1}{ }^{2}}{n_{1}}+\frac{s_{2}{ }^{2}}{n_{2}}-2 r\left(\frac{s_{1}}{\sqrt{n_{1}}}\right)\left(\frac{s_{2}}{\sqrt{n_{2}}}\right)}}
$$

Keterangan:

$\bar{x}_{1}=$ Rata-Rata Pretest

$\bar{x}_{2}=$ Rata-Rata Posttest

$s_{1}=$ Simpangan Baku Pretest

$s_{2}=$ Simpangan Baku Protest

$s_{1}{ }^{2}=$ Varians Pretest

$\mathrm{s}_{2}{ }^{2}=$ Varians Posttest

$r=$ Korelasi Antara 2 Sampel

Kriteria penilaian,

jika $-t_{\text {tabel }} \leq t_{\text {hitung }} \leq t_{\text {tabel }}$, maka $\mathrm{H}_{0}$ diterima.

jika $-t_{\text {tabel }}>t_{\text {hitung }}>t_{\text {tabel }}$, maka $\mathrm{H}_{0}$ ditolak.

\section{HASIL DAN PEMBAHASAN}

Hasil penelitian dari pengaruh metode bercerita terhadap kemampuan mengungkapkan bahasa anak usia 5-6 tahun TK Pertiwi 1 Banjarsari Desa Banjarsari Nganjuk menjelaskan secara rinci mengenai pengaruh metode bercerita terhadap kemampuan mengungkapkan bahasa anak usia 5-6 tahun TK Pertiwi 1 Banjarsari dari sebelum adanya perlakuan dan sesudah diberi perlakuan. Adapun hasil penelitian ini dapat disajikan dalam tabel 1. 
Tabel 1 Data Selisih (Beda) Nilai Pretest dan Postest Kemampuan Mengungkapkan Bahasa Anak Usia Dini 5-6 Tahun Di TK Pertiwi 1 Banjarsari

\begin{tabular}{|c|l|c|c|c|}
\hline No. & Nama & Pretest & Postest & $\begin{array}{c}\text { Selisih } \\
\text { (Beda) }\end{array}$ \\
\hline 1. & ADA & 1,61 & 3,67 & 2,06 \\
\hline 2. & RF & 1,72 & 3,19 & 1,47 \\
\hline 3. & KPM & 1,39 & 2,81 & 1,42 \\
\hline 4. & APM & 1,53 & 3,53 & 2 \\
\hline 5. & DPA & 1,83 & 3,47 & 1,64 \\
\hline 6. & SA & 1,72 & 3,50 & 1,78 \\
\hline 7. & TAM & 1,67 & 3,42 & 1,75 \\
\hline 8. & AGR & 2,00 & 3,50 & 1,5 \\
\hline 9 & MAK & 1,83 & 3,67 & 1,84 \\
\hline 10. & KAM & 1,83 & 3,67 & 1,84 \\
\hline 11. & EAP & 1,83 & 3,28 & 1,45 \\
\hline 12. & DDC & 1,39 & 3,61 & 2,22 \\
\hline 13. & ERAP & 1,56 & 3,61 & 2,05 \\
\hline 14. & MDAP & 1,86 & 3,22 & 1,36 \\
\hline 15. & NDS & 2,06 & 3,28 & 1,22 \\
\hline 16. & MKDA & 1,67 & 3,75 & 2,08 \\
\hline 17. & NKM & 1,67 & 3,53 & 1,86 \\
\hline 18. & MNI & 1,83 & 3,22 & 1,39 \\
\hline 19. & MVF & 1,56 & 3,19 & 1,63 \\
\hline
\end{tabular}

Berdasarkan tabel 1 di atas dapat diketahui bahwa terdapat peningkatan kemampuan mengungkapkan bahasa anak usia 5-6 tahun di TK Pertiwi 1 Banjarsari. Diketahui selama kegiatan sebelum perlakuan (Pretest) terdapat 18 anak memiliki nilai yang masuk dalam kriteria masih berkembang (MB), 1 anak memiliki nilai yang dalam kriteria berkembang sesuai harapan $(\mathrm{BSH})$, dan pada kegiatan ini belum ditemukan anak yang masuk dalam kriteria berkembang sangat baik (BSB). Setelah anak diberi perlakuan (treatment) kemampuan mengungkapkan bahasa anak meningkat, yaitu terdapat 18 anak memiliki nilai yang dalam kriteria (BSB) dan 1 anak memiliki nilai dalam kriteri (BSH). Hal ini dapat disimpulkan bahwa penerapan metode bercerita terhadap kemampuan mengungkapkan bahasa anak mengalami peningkatan.

Selain berdasarkan paparan dan hasil tabel 1 dapat juga dibuktikan dari hasil perhitungan yang telah dilakukan peneliti dan dapat diketahui bahwa hipotesis $\left(\mathrm{H}_{0}\right)$ ditolak dan hipotesis alternative $\left(\mathrm{H}_{\mathrm{a}}\right)$ diterima. Dari perhitungan yang dilakukan peneliti diperoleh nilai $t_{\text {hitung }}$ lebih kecil dari kriteria keputusan yang telah ditetapkan oleh peneliti. Angka $t_{\text {hitung }}$ yang diperoleh yaitu -12,53 dan dibandingkan dengan nilai kriteria keputusan yaitu $t_{\text {tabel }}$ yang berjumlah -2,450. Dapat disimpulkan bahwa nilai $t_{\text {tabel }}$ lebih besar dibandingkan dengan nilai $t_{\text {hitung. Jika }}\left(t_{\text {tabel }}>t_{\text {hitung }}\right)(-2,450>-12,53)$ maka $\mathrm{Ha}$ diterima yang artinya terdapat pengaruh yang signifikan antara penerapan metode bercerita terhadap kemampuan mengungkapkan bahasa anak usia 5-6 tahun di TK Pertiwi 1 Banjarsari. Jadi metode bercerita dapat diterapkan untuk menstimulus kemampuan mengungapkan bahasa anak usia 5-6 tahun.

Suatu treatment atau perlakuan yang telah dilaksanakan yaitu dengan menggunakan metode bercerita untuk mengajarkan kemampuan mengungkapkan bahasa anak pada anak usia 5-6 tahun di TK Pertiwi 1 Banjarsari merupakan suatu bentuk upaya untuk meningkatkan kemampuan mengungkapkan bahasa anak. Pemberian perlakuan (treatment) yang diberikan oleh guru adalah dengan menggunakan metode bercerita. Pemilihan metode bercerita yang digunakan sebagai pemberian perlakuan ini disesuaikan dengan metode yng ditetapkan dalam Peraturan Menteri Pendidikan dan Kebudayaan Republik Indonesia Nomor 146 Tahun 2014 tentang Kurikulum 2013 yang menyebutkan bahwa salah satu metode pembelajaran yang diterapkan di Taman Kanak-Kanak yaitu metode bercerita. Metode bercerita merupakan suatu cara atau sistem pembelajaran yang diterapkan oleh guru melalui kegiatan berbicara.

Metode bercerita yang telah dilaksanakan pada saat pelaksanaan treatment disesuaikan dengan lagkah-langkah pelaksanaan metode bercerita menurut Moeslichatoen (2004:179) yaitu yang terdiri dari persiapan, pelaksanaan dan penutup. Selain itu, isi cerita yang akan disampaikan sebagai bentuk perlakuan pada anak disesuaikan dengan tahap usia anak seperti menurut Mukhtar Latif (2013:111) yaitu disesuaikan dengan dunia anak, minat anak dan tingkat usia anak.

Pelaksanaan treatment pertemuan pertama menggunakan teknik bercerita dengan boneka sedangkan pertemuan kedua menggunakan buku cerita. Menurut Moeslichatoen (2004:158) teknik bercerita 
teknik bercerita antara lain yaitu, membaca langsung dari buku cerita, bercerita dengan ilustrasi gambar dari buku, menceritakan dongeng, bercerita dengan papan flanel, bercerita dengan boneka, dramatisasi cerita, bercerita dengan jari-jari tangan. Pada saat kegiatan treatment terlihat anak sangat antusias mendengarkan cerita yang disampaikan pendidik. Anak menjadi tertarik dan memperhatikan pendidik. Hal ini senada dengan manfaat dari metode bercerita menurut Muhammad Fadlillah (2012:174). yang menyatakan bahwa metode bercerita dapat sebagai hiburan atau menarik perhatian anak.

Hasil penilaian pretest dan posttest menunjukkan bahwa metode bercerita merupakan metode yang tepat dalam mengembangkan kemampuan bahasa khususnya aspek kemampuan mengungkapkan bahasa. Hal ini dapat dilihat dari hasil postest yang menunjukkan bahwa kemampuan mengungkapkan bahasa pada anak usia 5-6 tahun di TK Pertiwi 1 Banjarsari mengalami peningkatan. Hasil postest jika dilihat dari indikator pernyataan terdapat indikator yang memperoleh skor nilai tertinggi yaitu pada indikator menjawab pertanyaan yang lebih kompleks, dan indikator berkomunikasi secara lisan, memiliki perbendaharaan kata, serta mengenal simbol-simbol meembaca dan menulis terdapat 19 anak meperoleh nilai Berkembang Sangat Baik (BSB) yang artinya anak mampu dalam kemampuan mengungkapkan bahasa secara tepat tanpa harus dibantu guru.

Berdasarkan uarian di atas mengenai hasil postest dapat diketahui bahwa kemampuan mengungkapkan bahasa anak mengalami peningkatan perkembangan. Perlakuan yang diberikan dapat diterima dengan baik oleh anak. Sehingga anak menjadi mampu dalam kemampuan berbahasanya. Kemampuan bahasa memang harus dikembangkan sejak anak usia dini karena bahasa merupakan hal yang sangat penting untuk digunakan berkomunikasi dengan orang lain.

Menurut Syamsu (2004:118) Bahasa adalah sarana berkomunikasi dengan orang lain tercakup semua cara untuk berkomunikasi, dimana pikiran dan perasaan dinyatakan dalam bentuk lambang atau simbol untuk mengungkapkan suatu pengertian. Jadi setiap orang memerlukan bahasa untuk berkomunikasi selama masa hidupnya. Pada dasarnya anak usia dini memiliki rasa keingin tahuan yang sangat kuat pada pengalaman baru dalam hidupnya.

Penerapan metode bercerita dalam proses pembelajaran yang diterapkan guru dapat memfasilitasi dan merangsang keingintahuan anak sehingga anak menjadi lebih banyak bertanya dan menjadi memiliki banyak kata atau perbendaharaan kata serta menjawab pertanyaan dari pendidik. Pernyataan tersebut senada dengan tujuan dari metode bercerita menurut Moeslichatoen (2004:170) yaitu: anak mampu mendengarkan dengan seksama terhadap apa yang disampaikan orang lain, anak dapat bertanya apabila tidak memahaminya, anak dapat menceritakan dan mengekspresikan terhadap apa yang didengarkan dan diceritakannya, sehingga hikmah dari isi cerita dapat dipahami dan lambat laun didengarkan, diperhatikan, dilaksanakan dan diceritakannya pada orang lain.

Hal ini menjadikan anak mengalami peningkatan dalam aspek kemampuan mengungkapkan bahasa. Kemampuan mengungkapkan bahasa harus dikembangkan sejak dini karena dapat membantu untuk berkomunikasi dengan orang-orang sekitar. Selain itu, agar anak memiliki pemahaman dalam berkomunikasi dengan individu lain baik anak maupun orang dewasa.

Berdasarkan hasil penelitian yang kemudian dianalisis dengan beberapa teori mengenai metode bercerita dan kemampuan mengungkapkan bahasa anak yang telah dipaparkan di atas, maka peneliti dapat menjawab rumusan masalah yang telah di paparkan pada Bab 1 bahwa ada pengaruh metode bercerita terhadap kemampuan mengungkapkan bahasa anak usia 5-6 tahun di TK Pertiwi 1 Banjarsari.

\section{SIMPULAN}

Berdasarkan hasil penelitian dan hasil pembahasan dapat disimpulkan bahwa terdapat pengaruh metode bercerita terhadap kemampuan mengungkapkan bahasa anak usia 5-6 tahun di TK Pertiwi 1 Banjarsari. Hal ini dibuktikan dari hasil analisis regresi menggunakan uji-t (T-Test), diketahi bahwa 
nilai $t_{\text {hitung }}<t_{\text {tabel }}(-12,53 \leq-2,450)$, maka $H_{0}$ ditolak dan $H_{a}$ diterima dengan taraf signifikan 5\%. Hal ini menunjukkan bahwa nilai $t_{\text {tabel }}$ lebih besar dari nilai $t_{\text {hitung, }}$, sehingga hipotesis nol $\left(H_{0}\right)$ ditolak dan hipotesis alternatif $\left(H_{a}\right)$ diterima. Sehingga $t_{\text {tabel }}>t_{\text {hitung }}$ atau terbukti bahwa terdapat pengaruh metode bercerita terhadap kemampuan mengungkapkan bahasa anak usia 5-6 tahun di TK Pertiwi 1 Banjarsari.

\section{DAFTAR PUSTAKA}

Armstrong, T. 2013. Kecerdasan Multipel Di dalam Kelas. Jakarta: PT Indeks.

Fadillah, M. 2012. Desain Pembelajaran PAUD. Jogjakarta: Ar-Ruzz Media.

Jamaris, Perkembangan dan Pengembangan Anak Usia Taman Kanak-Kanak, (Jakarta: Universitas Negeri Jakarta)

Latif, M, dkk. 2013. Orientasi Baru Pendidikan Anak Usia Dini. Jakarta: PT Fajar Interpratama Madiri.

Moeslichatoen. 2004. Metode Pengajaran di Taman Kanak-kanak. Jakarta: Rineka Cipta.

Peraturan Menteri Pendidikan Dan Kebudayaan Republik Indonesia Nomer 84 Tahun 2014 Pasal 1 Tentang Pendirian Satuan Pendidikan Anak Usia Dini.

Sugiyono. 2014. Metode Penelitian Pendidikan Pendekatan Kuantitatif, Kualitatif, dan $R \& D$. Bandung: Alfabeta.

Madyawati, L. 2016. Strategi Pengembangan Bahasa pada Anak. Jakarta: Prenada Media Group.

Mansyur, Y. 2009. Pengajaran Bahasa Secara Umum. Jakarta: Bumi Aksara. 